\title{
Managing Health and Safety Risk of Hepatitis B Transmission: A Study on the Knowledge and Practice of Non-Professional Blood Donors of Residential Halls of Dhaka University
}

\author{
${ }^{1}$ Sarmin Akter and ${ }^{2} \mathrm{Md}$. Abdus Sattar \\ Lecturer (Sociology), OS, Bangladesh Open University
}

\begin{abstract}
This article aims at portraying the present situation of Hepatities B in Bangladesh. Moreover, this article also tries to show the safety risk of Hepatities B transmission and knowledge and practice of NonProfessional Blood Donors of Residential Halls of Dhaka University, Bangladesh. This explorative research utilized quantitative method such as Survey to collect data. A number of 107 respondents are interviewed from different residential halls of Dhaka University. The major findings of this study shows that because of their carelessness, ignorance the risk of infection of Hepatities B is high among male respondents than female and unmarried than married. In addition, this paper argues that in future if we do not take necessary steps to increase the awareness level of our large population about the risk of Hepatities $B$, it will be a disastrous disease for our country.
\end{abstract}

Key Words: Hepatitis B virus (HBV), non-professional, Blood Donors, Residential Halls, Disastrous.

\section{Introduction}

The infection of Hepatitis B virus (HBV) is one of the causes of morbidity and mortality all over the world. The virus has already infected more than 2,000 million people globally. There are 350 million estimated carriers. In $80 \%$ cases HBV virus is responsible for liver cancer and cirrhosis. The prevalence of hepatitis B virus from country to country depends upon complex behavior, environment of host factors etc (Mobin, 1998). Hepatitis B is a great public health problem for Bangladesh also.

In Bangladesh the extension and magnitude of the problem is not definitely known. But from the available data it can be said that HBV infection is prevailing endemically in our country. The mode of transmission of the disease is various but in Bangladesh unscreened blood transfusion is one of the commonest of all. About 200, 000 bags of blood are being transfused annually in different hospitals and clinics in our country. Out of these $10-20 \%$ of the donors are non-professionals who are the volunteer donors (Shahidullah et al., 1998). In Bangladesh about $7.5 \%$ of the adult population carries this virus (Ibid).

\section{Social and Bio-Medical Context Of Hepatitis B Virus WHAT IS HEPATITIS B?}

Hepatitis B is an infectious illness of the liver caused by the hepatitis B virus (HBV) that affects hominoidea, including humans. The hepatitis B virus attacks the liver. Sometimes, people with hepatitis B do not feel sick at all. But they can still pass the disease on to other people. They are called carriers. In other cases, hepatitis B makes people very sick. It can cause serious damage to the liver and long lasting (or chronic) liver disease. Hepatitis B is one of the main reasons people get liver cancer. There is no cure for hepatitis B.

\section{MODE OF TRANSMISSION:}

The virus may be transmitted by contact with infected blood or body fluids such as through household or sexual contact with an infected person. The virus can be spread by the following routes:

- Sharing or use of contaminated equipments during the use of drug.

- Vertical transmission (mother to baby) from an infectious mother to her unborn child.

- Sexual transmission

- Sharing tooth brushes, razors, nail clippers etc.

- Reception of infectious blood (via transfusion) or infectious blood products (for example, clotting factors)

- Needle stick or other sharps injuries

- Tattooing and body piercing

- Have multiple sex partners

- Homosexuals 
- Live in the same house with someone who has life long (chronic) HBV infection.

- A hem dialysis patient

- Infant/child or immigrant from areas with high rates of infection.

\section{HOW LONG IS A PERSON ABLE TO SPREAD THE VIRUS?}

The virus can be found in blood and other body fluids several weeks before symptoms appear and generally persists for several months afterword. Approximately, 10 percent of infected adults may become long term (chronic) carriers of the virus and infants infected at birth have a 90\% chance of becoming chronically infected.

\section{HIGH RISK GROUPS:}

- Homosexuals

- Prostitutes

- Health care and laboratory persons

- Blood donors

- Infants of HBV carrier mothers

- Patients who are immune compromised

- Surgeons

- Drugs users

\section{HOW CAN HEPATITIS B VIRUS BE PREVENTED?}

The most effective means of preventing hepatitis B virus infection is to avoid contact with the blood and body fluids, including semen and vaginal secretions of infected individuals. People who have hepatitis B virus infection should avoid sharing items that could infect others, such as razors, toothbrushes etc. Protect sex partners from exposure to semen, vaginal fluids through the proper use of condoms. There are several vaccines available to prevent hepatitis B. Vaccination should be considered by people at high risk of infection: male, homosexuals and heterosexuals, people who receive hem dialysis or blood products, household and sexual contacts of HBV carriers, and users of street drugs who share needles. Moreover, many health care and laboratory workers who handle blood and other body fluids should also be vaccinated. People who come into direct contact with the blood or body fluids of an HBV carrier may receive one or more injections of hepatitis B immune globulin, sometimes in combination with hepatitis B vaccine. Immune globulin offers temporary protection, while the vaccine provides long lasting immunity.

In an effort to eliminate chronic carriers of HBV, the U.S. Centers for Disease Control and Prevention (CDC) recommends that all newborn babies be vaccinated against the hepatitis $B$ virus. The CDC and other groups have recommended that pregnant women be screened for hepatitis B as part of routine prenatal care. If the mother is infected, her baby can be given hepatitis B immune globulin and vaccine immediately after birth.

\section{Global Perspectives Of Hepatitis B Virus:}

Infection by hepatitis B virus is a serious public health problem in all parts of the world. About a third of the world population has been infected at one point in their lives, including 350 million who are chronic carriers (Wikipedia, 2014). HBV infection can cause serious liver disease, including liver failure and liver cancer. More than 240 million people have chronic (long-term) liver infections. About 6, 00000 people die every year due to the acute or chronic consequences of hepatitis B (WHO, 2014). HAV and HBV infection can have serious consequences for people with HIV, as their immune systems might be compromised.

According to the Centers for Disease Control (CDC), approximately 46,000 new cases of hepatitis B occurred in the United States in 2006. In the United States, rates of new infection were highest among people aged 25 to 44 years (3.1 cases per 100,000 population) and lowest among those younger than 15 years of age (0.02 per 100,000). This reflects the major modes of transmission of hepatitis B (sexual transmission, illicit drug use, exposure to infected blood) and the effect of universal vaccination of infants. In the United States an estimated 800,000 to 1.4 million people are chronically infected with hepatitis B (Medicine net, 2014).

Hepatitis B is one of the major infectious diseases of mankind: of 360 million chronic carrier's world wide- $78 \%$ in Asia, 16\% in Africa, 3\% in South America, 3\% in Europe, North America and Oceania combined (Syeed, Ahmed, Siraji, Hoque, 2007). In general, the infection rate of Hepatities B is lowest in countries or areas with high standards of living.

The HBV infection is a global problem, with $66 \%$ of the entire world's population living in areas where there are high levels of infections (Moinul, 2002). The virus causes 60-80 Percent of all primary liver cancer, which is one of the three top causes of cancer death in east, the pacific basin and sub-Saharan Africa (Ibid).

The world wide prevalence of HBV is in Northern Europe, Eastern Europe, central Europe, North 
America and Australia region are, HBV is $02-0.5 \%$, Anti-HBS is $4-6 \%$, Neonatal infection is rare, childhood infection is infrequent. In countries Eastern Europe, Mediterranean, USSR, Southeast Asia, Central America and South America HBsAg Position is 2-7\%, Anti HBS is 20-55\%, Neo natal infection and Child hood infection is frequent (Moinul, 2002.)

\section{Hepatitis B Virus Prevalence In Asian Context:}

The infection of Hepatitis B is very common in Asian region. Originally known as "serum hepatitis", the disease has caused epidemics in parts of Asia and Africa, and it is endemic in China. Hepatitis B prevalence is highest in sub-Saharan Africa and East Asia. Most people in these regions become infected with the hepatitis B virus during childhood and between $5-10 \%$ of the adult population are chronically infected. In the Middle East and the Indian subcontinent, an estimated 2-5\% of the general population is chronically infected (WHO, 2014).

Of the 350 million to 400 million individuals worldwide infected with the hepatitis B virus (HBV), one-third reside in China, with 130 million carriers and 30 million chronically infected (WHO, 2014). Since the Expanded Program on Immunization (EPI) beginning 1992, the prevalence of HBV has declined, especially among children 3 to 12 years old (Ibid). Every year, 300,000 people die from HBV-related diseases in China, including 180,000 patients with hepatocellular carcinoma (HCC) (Ibid). However, the incidence of hepatitis B is still increasing, from 21.9 in 100,000 people in 1990 to 53.3 in 100,000 in 2003(Ibid). That increase has occurred despite a vaccination program for newborn babies since the 1990s, which showed good effectiveness for reducing chronic HBV infection in children.

Of the estimated 50 million new cases of hepatitis B virus (HBV) infection diagnosed annually, 5-10\% of adults and up to $90 \%$ of infants will become chronically infected, $75 \%$ of these in Asia where hepatitis B is the leading cause of chronic hepatitis, cirrhosis and hepatocellular carcinoma (HCC) (Ibid). In Indonesia, 4.6\% of the population was positive for $\mathrm{HBsAg}$ in 1994 and of these, $21 \%$ were positive for $\mathrm{HBeAg}$ and $73 \%$ for anti$\mathrm{HBe} ; 44 \%$ and $45 \%$ of Indonesian patients with cirrhosis and $\mathrm{HCC}$, respectively, were HBsAg positive. In the Philippines, there appear to be two types of age-specific HBsAg prevalence, suggesting different modes of transmission. In Thailand, 8-10\% of males and 6-8\% of females are HBsAg positive, with HBsAg also found in $30 \%$ of patients with cirrhosis and $50-75 \%$ of those with HCC. In Taiwan, 75-80\% of patients with chronic liver disease are HBsAg positive, and $\mathrm{HBsAg}$ is found in $34 \%$ and $72 \%$ of patients with cirrhosis and $\mathrm{HCC}$, respectively. In China, $73 \%$ of patients with chronic hepatitis and $78 \%$ and $71 \%$ of those with cirrhosis and $\mathrm{HCC}$, respectively, are HBsAg positive. In Singapore, the prevalence of HBsAg has dropped since the introduction of $\mathrm{HBV}$ vaccination and the HBsAg seroprevalence of unvaccinated individuals over 5 years of age is $4.5 \%$. In Malaysia, $5.24 \%$ of healthy volunteers, with a mean age of 34 years, were positive for HBsAg in 1997. In the highly endemic countries in Asia, the majority of infections are contracted postnatally or perinatally(Ibid).

In the parts of China, Southeast Asia and tropical Africa the prevalence of HBV is $8-20 \%$, Anti-HBs is $70-95 \%$, Neonatal and Childhood infection is very frequent (Moinul, 2002).

\section{Hepatitis B Virus Prevalence in Bangladesh:}

Bangladesh is a densely populated country in the world with a total population of 120.8 million (BBS, 1996). Concurrent natural, socio-economic conditions and existing primary health care system expose them to health hazards. More than one million deaths occurs form complication of HBV infection every year. Approximately 5 to $10 \%$ of infected patients become long time carrier of the virus and it is estimated that there are about 350 million carriers exists in Bangladesh (Shahidullah et al. 1998).

In Bangladesh the prevalence of viral hepatitis is not low. Since there is no extensive study, the extent and magnitude of problem is not known and accurately determined. In Bangladesh 200000 bags of blood are needed for the patients per year. Within the amount $80 \%-90 \%$ blood are collected from the professional blood donors. Report from a small study revels around $18 \%$ of commercial blood donors in Dhaka city as HVB carriers (Dr. Islam Moinul, 2002).

A research study showed a higher prevalence of HBV positive case (19.6\%) among the professional blood donors compared to only $10.9 \%$ among the non-professional donors in Bangladesh. It reveals that the respondents know about the Hepatitis B with only little knowledge about the mode of its transmission (Shahidullah, 2000). Another study done by Muhammad, et. al (1995) at Sher-E-Bangla Mdeical College Hospital, Barisal which showed that $26 \%$ carrier rate among commercial blood donors. In addition, a study in Dhaka City revealed 20\% HBV positive among professional blood donors, while sahidullah showed in 1996 among 107 non professional blood donors that 5.6\% were HBV positive (JOPSOM, 1998). 


\section{(a) General Objective:}

\section{Objectives Of The Study:}

To know the risk of transmission of hepatitis B virus among the non-professional blood donors and the knowledge and practice about the management of health of the respondents.

\section{B) Specific Objectives:}

(i) To identify non-professional blood donors.

(ii) To determine the socio-economic and demographic characters of non-professional blood donors.

(iii)To whom they are donating blood.

(iv)To identify the risk factors related to the donation of blood by the non- professional blood donors.

(v) To know the rate of spread ability among non-professional blood donors.

vi) To identify the exposure of the donors to HBV during blood donation.

(vii) To know their knowledge about HBV .

(viii) To know their social attitude and practice.

(ix) To know about risk factors related to HBV.

\section{HYPOTHESES:}

a) The lack of health management and knowledge of risk factor is the cause of HBV infection.

b) There is knowledge about HBV infection among non-professional donors or not.

c) If the knowledge and practice is increase the HBV infection will be decreased.

d). Proper knowledge about the mode of transmission of HBV can prevent the prevalence of HBV.

VARIABLES:

\section{Conceptual Framework Of The Study}

Dependent variable: knowledge and practice of donors.

Independent variable: Making health and safety risk of HBV transmission.

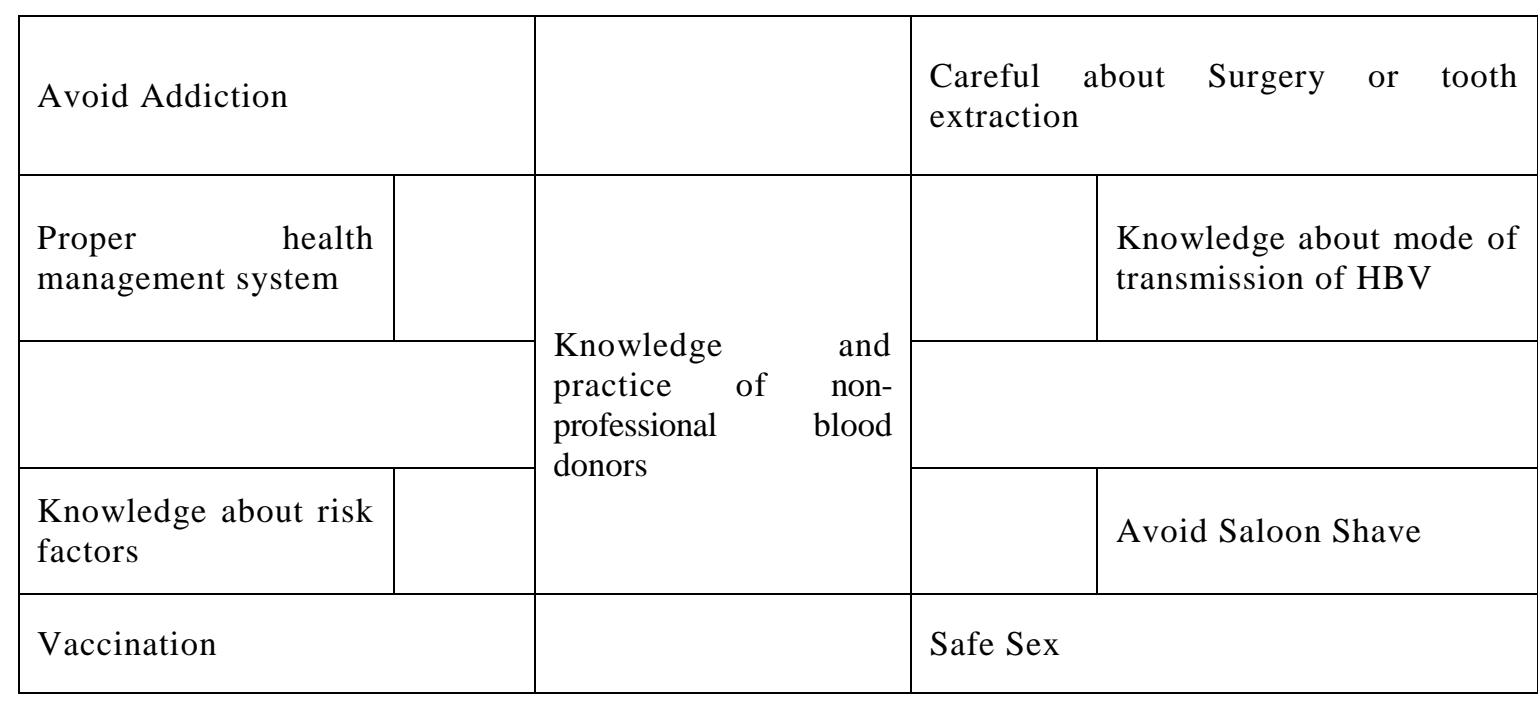

The Study Site:

IV. Methodology Of The Study:

The study was carried out among non-professional blood donors stayed in the residential halls of Dhaka University.

\section{Study Unit:}

Non-Professional blood donors of the residential halls of Dhaka University

Reliability and Validity:

Data were collected from reliable sources through interview which will prove its validity.

\section{Techniques of Data Collection:}

This study used quantitative methodology and data was collected based on the pre-tested structured 
interview schedule by the researchers through face to face interview with the respondents.

Sampling:

One hundreds and seven blood donors are selected purposively for the study.

Data Processing and Analysis:

Collected data were transferred to the master tabulation sheet after proper checking, verifying and editing as per the specific objectives and key variables. Tables were made on available data and satisfied procedures were applied in analyzing the data.

Findings of the Study:

GRAPH -1: DEMOGRAPHIC CHARACTERISTICS OF THE RESPONDENTS:

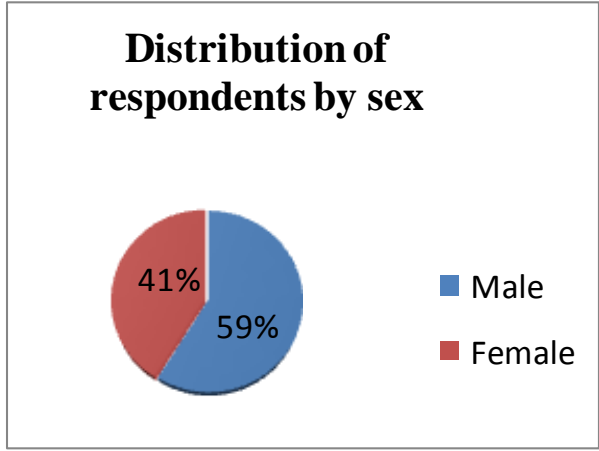

Distribution of marrital status of the respondents

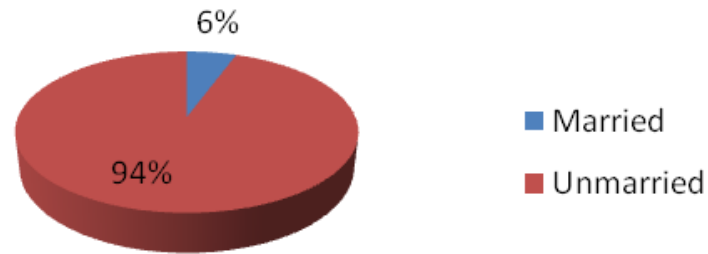

There are one hundred and seven non-professional donors stayed in the residential halls of Dhaka University and among them 63 (59\%) were male and $44(41 \%)$ were female. According to marital status $6(6 \%)$ were married and $101(94 \%)$ were unmarried.

GRAPH 2: Health Status:
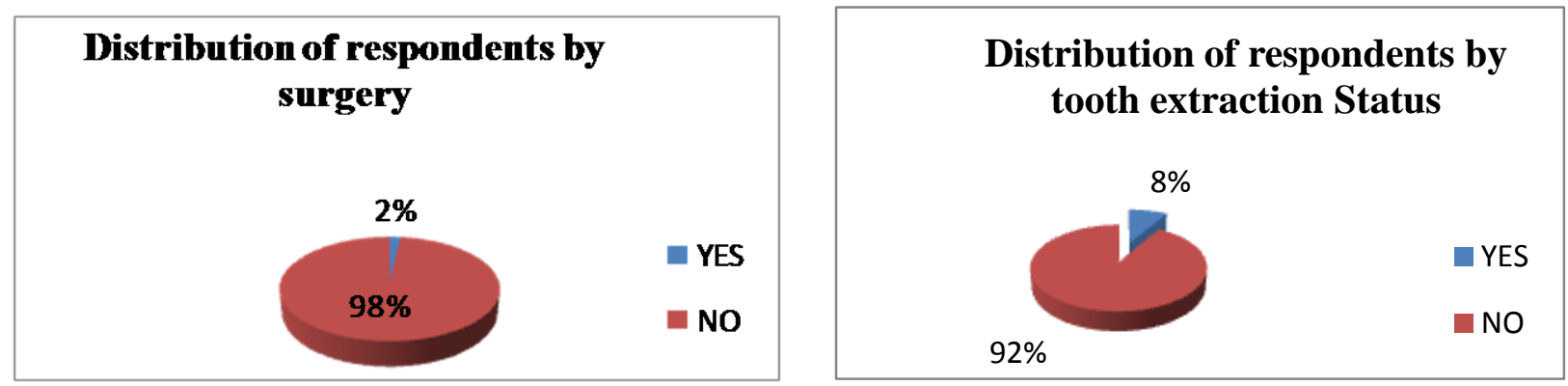

Among 107 respondents only 2\% were found to have had surgical intervention and the rest of $98 \%$ donors did not have any history of surgery. Among the donors $8 \%$ had their tooth extraction within the last two years and the rest $92 \%$ donors had no history. 
Managing Health and Safety Risk of Hepatitis B Transmission: A Study on the Knowledge...

GRAPH 3: Distribution of Respondents by User of Drug

Distribution of respondents by the history of injection

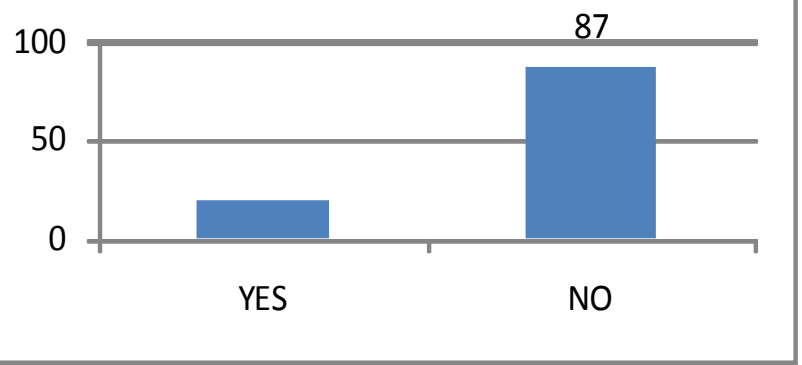

\section{Distribution of respondents by} addiction

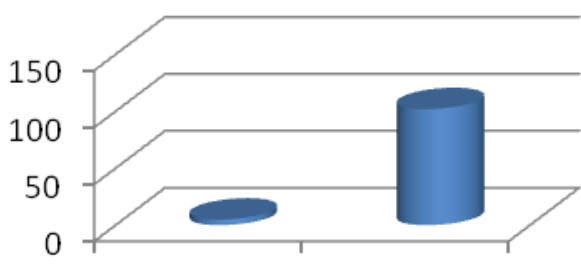

YES

Among 107 respondents, $20(19 \%)$ had the history of injection and rest $87(81 \%)$ did not have the history of injection. Only $5(4 \%)$ had the habit of addiction and the rest $102(96 \%)$ had no such habit.

\section{GRAPH 4: Distribution of Respondents According To Past History of Jaundice}

\section{Distribution of respondents by the past history of Jaundice}

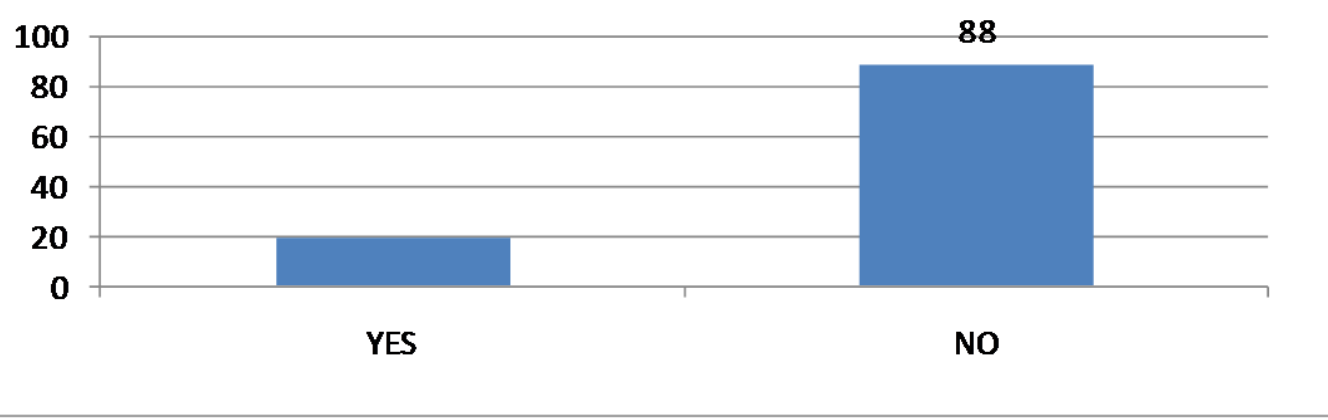

Among the 107 non professional blood donors only $19(18 \%)$ had the history of suffering from jaundice and the rest of the respondents had no history of jaundice.

\section{Respondent's Medical Status}

Table 1: Status of blood examination among blood donors

\begin{tabular}{|c|c|c|}
\hline & No. of respondents & Percentage \\
\hline Blood examination & 11 & 10 \\
\hline Yes & 96 & 90 \\
\hline Total & 107 & $100 \%$ \\
\hline
\end{tabular}

Above table shows that 11(10\%) donors had the history of blood test and rest $96(90 \%)$ did not have the history of blood test.

\section{Respondent's Awareness about Hepatitis B Virus}

Table 2: Knowledge about Hepatitis B Virus infection:

\begin{tabular}{|c|c|c|}
\hline Knowledge of HBV & No. of respondents & Percentage \\
\hline Yes & 57 & 53.3 \\
\hline
\end{tabular}


Managing Health and Safety Risk of Hepatitis B Transmission: A Study on the Knowledge...

\begin{tabular}{|c|c|c|}
\hline No & 50 & 46.7 \\
\hline Total & 107 & $100 \%$ \\
\hline
\end{tabular}

Above table shows that among a total of 107 respondents 57 (53\%) have knowledge about HBV infection and $50(47 \%)$ did not have such knowledge.

Table 3: Vaccination against HBV among donors

\begin{tabular}{|c|c|c|}
\hline Vaccination against HBV & No. of respondents & Percentage \\
\hline Yes & 30 & 28 \\
\hline No & 77 & 72 \\
\hline Total & 107 & $100 \%$ \\
\hline
\end{tabular}

Among 107 non professional blood donors 30 (28\%) were vaccinated against HBV and the rest 77 (72\%) were not vaccinated.

Table 4: Distribution of sexual exposure among donors:

\begin{tabular}{|l|c|c|}
\hline Sexual exposure & No. of respondents & Percentage \\
\hline Girl Friends & 9 & $8 \%$ \\
\hline Boy Friends & 3 & $3 \%$ \\
\hline No history & 95 & $100 \%$ \\
\hline Total & 107 & \\
\hline
\end{tabular}

Regarding high risk sex practice, $9(8 \%)$ were exposed to girl friends, 3 (3\%) were exposed to boy friends and $95(89 \%)$ had no history of illicit sexual exposure.

Table 5: Distribution of saloon shaves among Donors:

\begin{tabular}{|c|c|c|}
\hline Saloon shave & No. of respondents & Percentage \\
\hline Yes & 63 & $49 \%$ \\
\hline No & 44 & $100 \%$ \\
\hline Total & 107 & \\
\hline
\end{tabular}

Among the male donors, 63 (59\%) had the history of saloon shaving and 44 (41\%) did not have any history of shaving in a saloon.

Table 6: Blood transfusion among donors:

\begin{tabular}{|c|c|c|}
\hline Blood transfusion & No. of respondents & Percentage \\
\hline Yes & 9 & $8 \%$ \\
\hline No & 98 & $92 \%$ \\
\hline Total & 107 & $100 \%$ \\
\hline
\end{tabular}

Among a total of 107 non-professional blood donors $9(8 \%)$ had the history of blood transfusion and the rest $98(92 \%)$ of the donors had no history of blood transfusion. 
Managing Health and Safety Risk of Hepatitis B Transmission: A Study on the Knowledge...

\section{Result Of Hepatitis B Status According To The Table:}

Graph 1:No. of HBV positive respondents

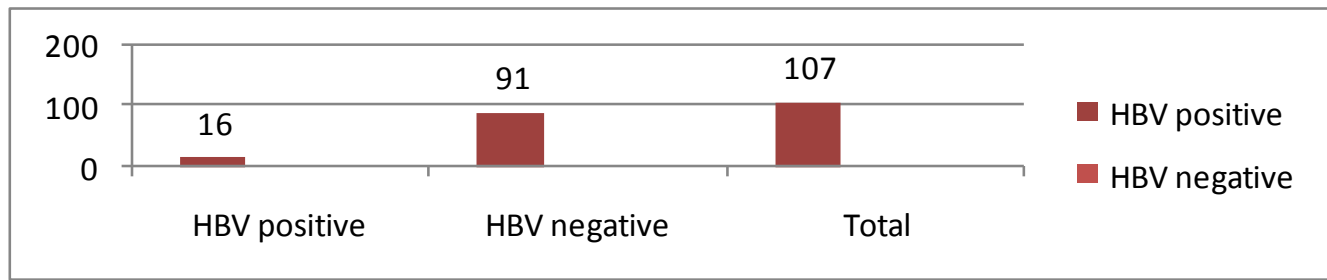

Researchers found that among 107 respondents 16 are HBV positive and 91 are negative. The percentage of infected rate is $14.95 \%$.

Graph 2: Distribution of Hepatitis B Virus status according to sex:

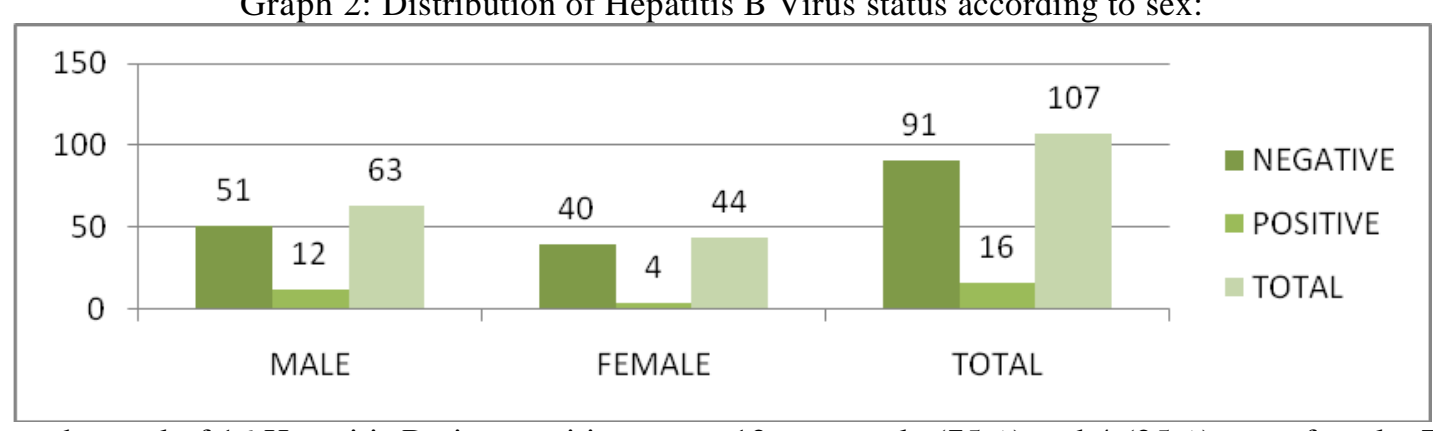

Among the total of 16 Hepatitis B virus positive cases, 12 were male (75\%) and 4 (25\%) were female. There is a positive relationship between Hepatitis B virus status and sex status. That means, Hepatitis B Virus attacked male person more than female. Because of male's addiction, saloon shaves, blood transfusion, lack of vaccination etc the infection level of $\mathrm{HBV}$ is high among males.

Graph 3: Hepatitis B Virus Status in Relation to Marital Status:

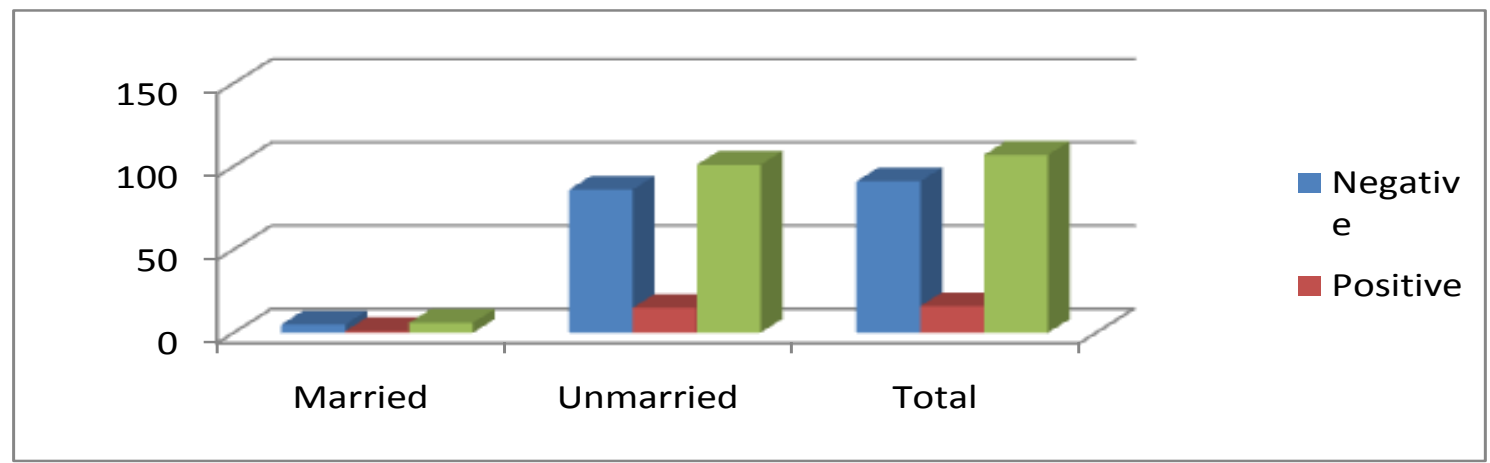

Among 16 positive cases, one married person is found. So, there exists a positive relationship between HBV status and marital status. According to marital status HBV infection is found more among unmarried persons than married persons. The reasons are unmarried person's carelessness, experience of premarital sex, lack of knowledge etc.

Graph 4: Hepatitis B Virus Status in Relation to Tooth Extraction:

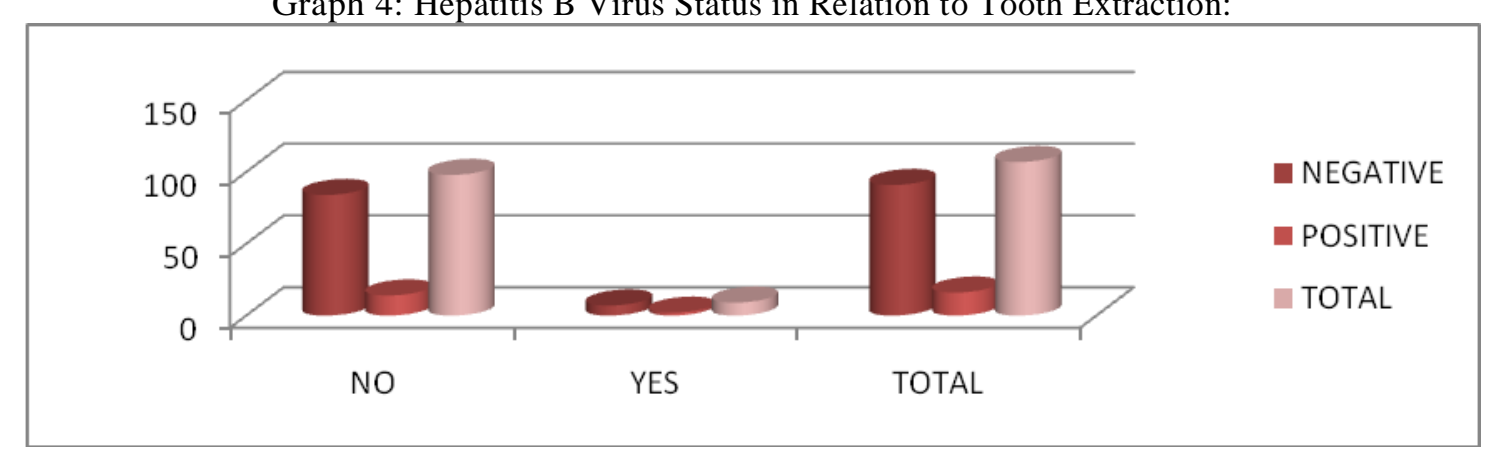


Among a total of 16 Hepatitis B Virus positive cases only 2 had the history of tooth extraction. There is positive relationship between Hepatitis B virus status and tooth extraction. Tooth extraction can spread Hepatitis B virus through surgery. If a Hepatitis B positive person's germ is transferred to well health persons, he/she would be attacked by Hepatitis B virus. For that reason persons should be careful.

Graph 5: Hepatitis B Virus Status in Relation to Surgery:

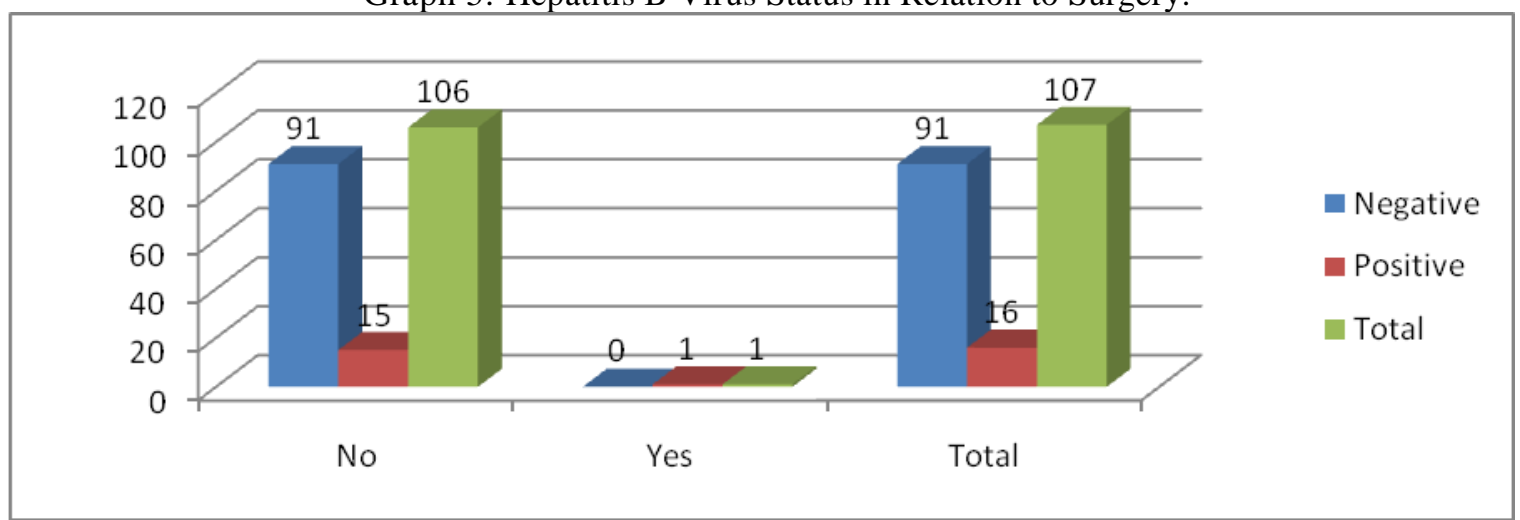

Among a total of $16 \mathrm{HBV}$ positive cases one had the history of surgery. Here data shows that HBV can be spread through surgery because of the carelessness of both doctors and patients. So, it can be said that knowledge, practice and awareness should increase among both of them.

Graph 6: Hepatitis B Virus Status in Relation of Injection:

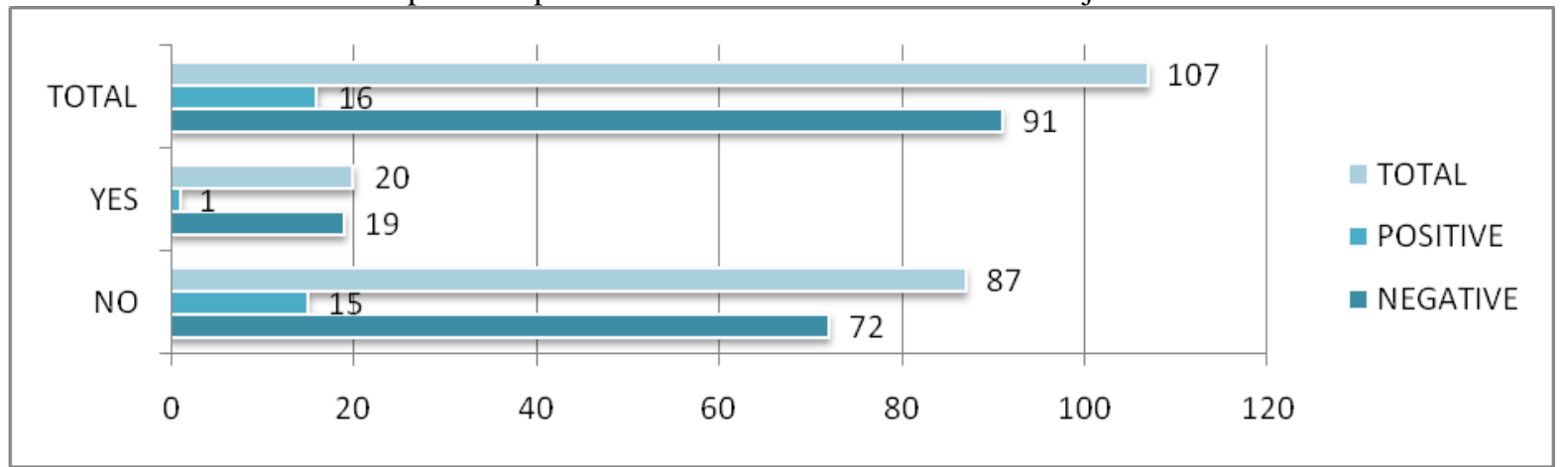

Among 107 respondents a total of 16 positive cases only one injected Hepatitis B positive persons is found. By Injection Hepatitis B virus can also be speared. So, one time use syringe should be used.

Graph 7: Hepatitis B Virus Status in Relation to Addiction:

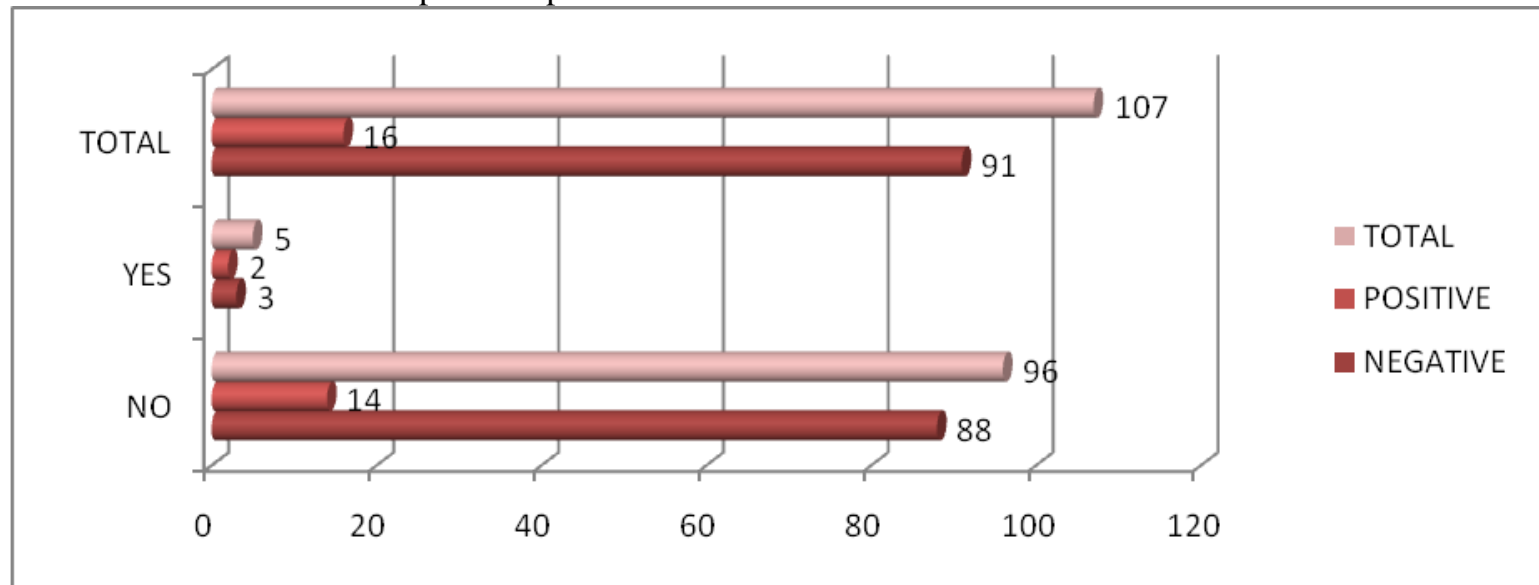

Among a total of 16 positive cases two had the history of addiction. There is a relationship between Hepatitis B virus and addiction. One of the important causes of Hepatitis B virus infection is addiction. A long time addicted person or a person who take drug through injection it is a serious risk for them to attack by the Hepatitis B virus for using one syringe by many addicted persons. It is a risk behavior for Hepatitis B virus infection. Knowledge and awareness should be increased for this. 
Graph 8: Hepatitis B Virus Status in Relation to Blood Examination

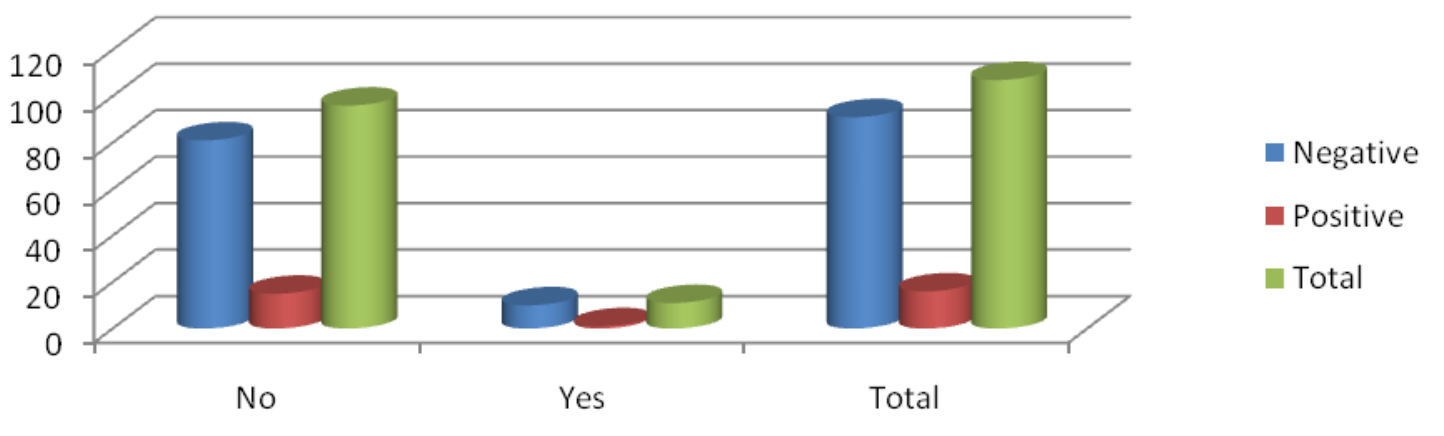

Among a total of 16 Hepatitis B Virus positive cases only one have the history of blood examination. There is a positive relationship between Hepatitis B virus and blood examination. During the test of blood Hepatitis B virus can be spread among person to person by syringe.

Graph 9: Hepatitis B Virus Status in Relation to Vaccination against Hepatitis B Virus among Donors:

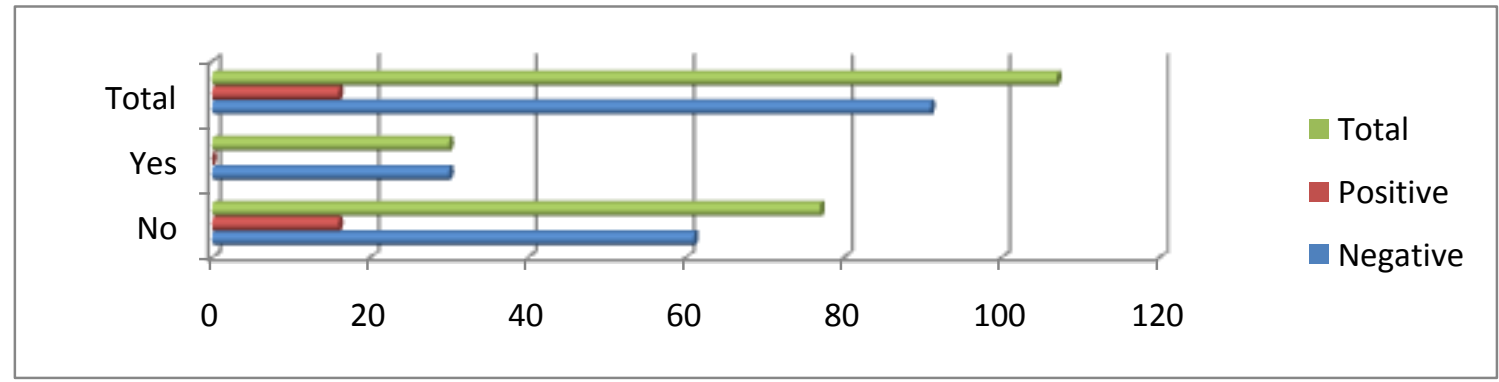

Among a total of 16 Hepatitis B Virus positive cases none had the history of vaccination against Hepatitis B Virus. There is a positive relationship between vaccination and Hepatitis B virus infection.

Graph 10: Hepatitis B Virus Status in Relation to Jaundice among Non-Professional Donors:

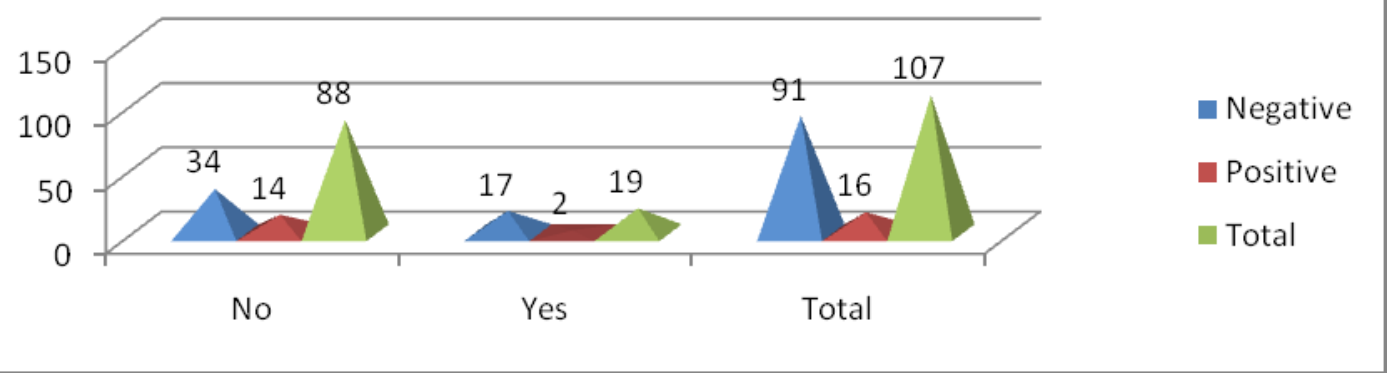

Among 107 respondents nineteen had the history of suffering from Jaundice and total 16 positive cases two respondents had the history of jaundice.

\section{AWARENESS AND HEPATITIS B VIRUS STATUS:}

Graph 11: Hepatitis B Virus status in relation to knowledge about Hepatitis B Virus among donors:

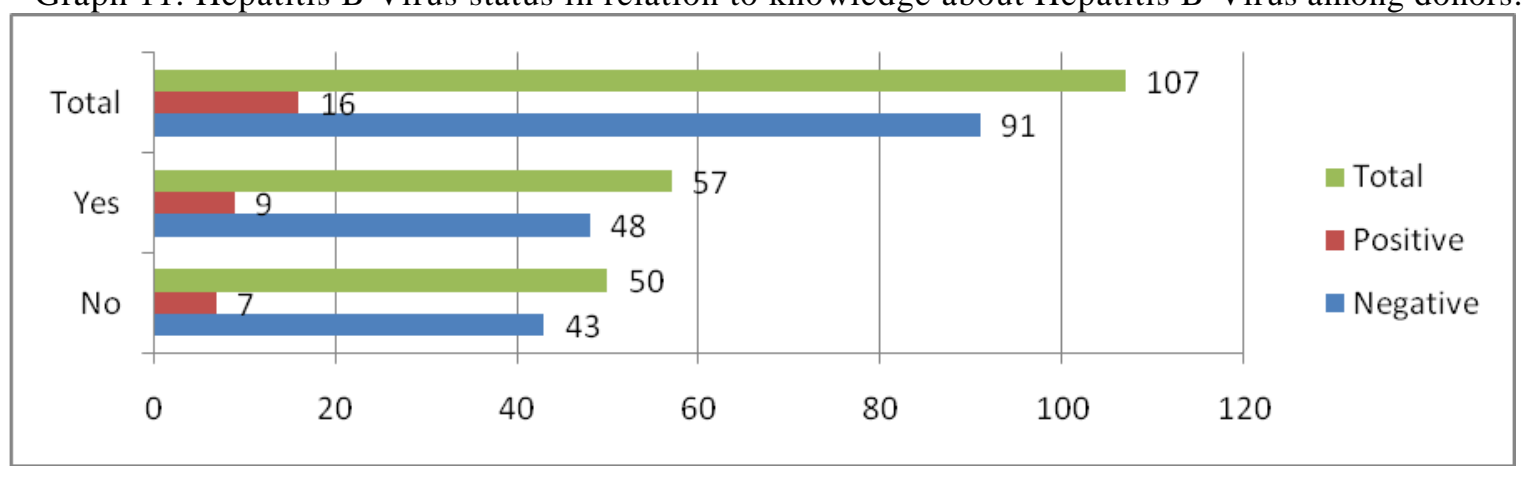


Among a total of 16 Hepatitis B Virus positive cases 7 did not have the knowledge about Hepatitis B Virus and 9 had the knowledge about Hepatitis B Virus infection. Lack of knowledge among individuals is one of the causes of Hepatitis B virus infection. The hypotheses of the study and the research result are seen positive. Our Hypothesis is if knowledge about HBV is increased the infection of HBV will be decreased. That means there is a relationship among Hepatitis B virus and knowledge and practice.

Graph 12: Hepatitis B Virus Status in Relation to Saloon Shave among Donors:

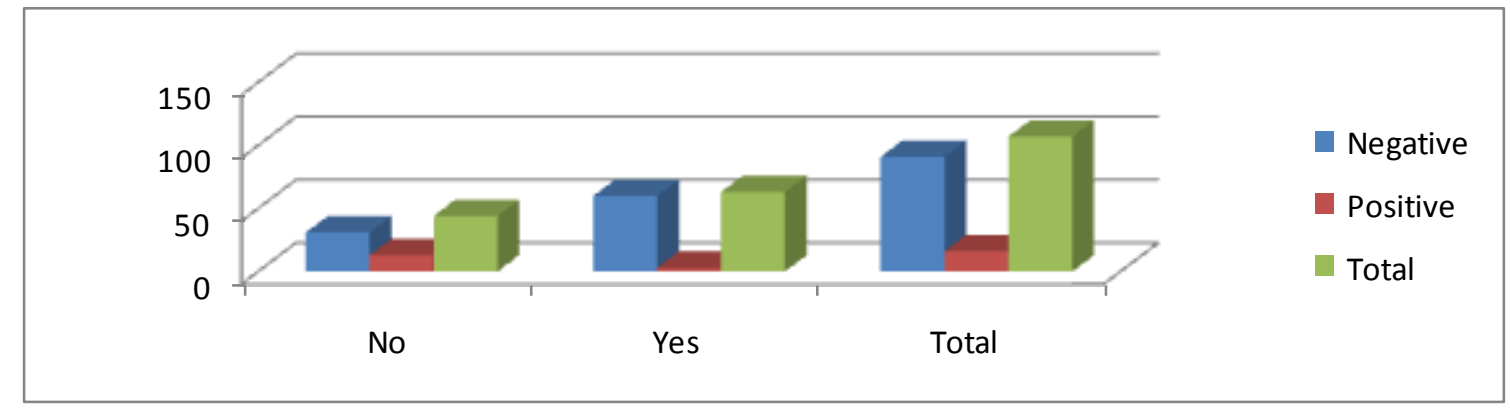

Among a total of 16 positive cases 3 had the history of saloon shaves and the rest 13 had no-history of saloon shaves. Persons can be attacked by the Hepatitis B virus if he uses the infected shave instruments. Shaving instruments which are used by many members or saloon shave should be avoided. Social awareness and knowledge should be increased for that. So there is a positive relationship among saloon shaves and Hepatitis B virus.

Graph 13: Hepatitis B Virus Status in Relation to Blood Transfusion:

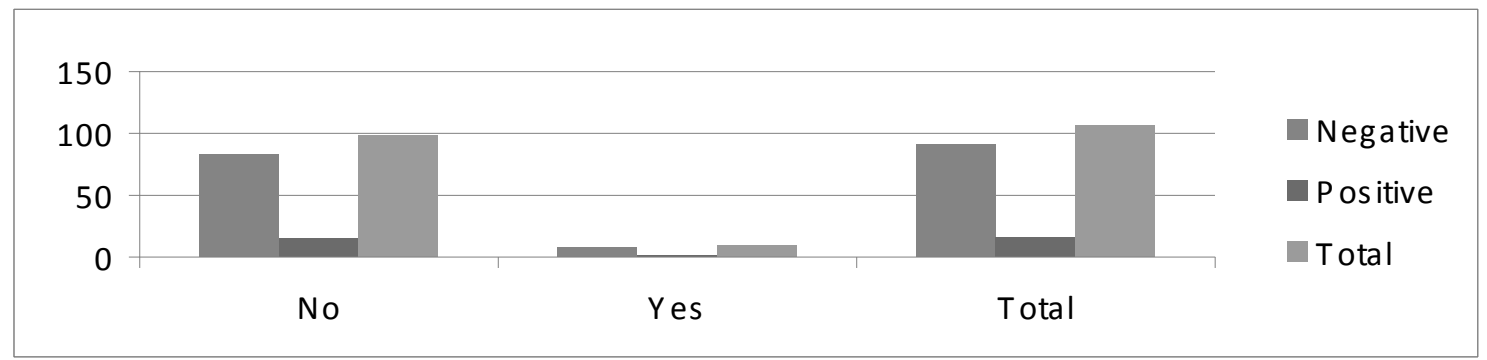

Among a total of 16 Hepatitis B Virus positive cases 1 had the history of blood transfusion and 15 did not have the history of blood transfusion.

The main factor of Hepatitis B virus transmission is blood transfusion. If a HBV positive person gives blood to another person he/she would be attacked by Hepatitis B virus. So, we should test the blood before taking it.

\section{Discussion}

Hepatitis B virus infection is a major cause of morbidity and mortality related to liver diseases. It is endemic all over the world. The prevalence of the diseases is high in developing countries where environmental and socio-economic conditions are poor.

In this study researcher has tested knowledge and practice of non-professional blood donors managing health and safety risk of HBV transmission. Among a total of 107 respondents 57 (53\%) had knowledge about HBV infection and 50 (47\%) did not have such knowledge. They did not know about the mode of transmission, risk factors of HBV infection. There knowledge is so limited in the field of health management system. The results also showed the HBV status in relation to knowledge about HBV among donors. Among a total of $16 \mathrm{HBV}$ positive cases 7 did not have the knowledge about HBV and 9 had the knowledge about HBV infection.

In this research one of the important hypotheses is if the knowledge and practice is increased the HBV status will be decreased. This means that there is a relationship among HBV status of blood donors and knowledge. To prove this researcher had done chi-square test the result of the test is there are a little relationship among HBV status and knowledge among the non-professional blood donors.

As the donors are the students of Dhaka University, they come from all corners of Bangladesh and from all social, religion and ethnical groups, at the same time they are from well educational and financial background. For that information were collected from them to know about their knowledge level. 
The reasons behind lack of knowledge of Hepatitis B Virus infection among people of Bangladesh are as follows:

- Lack of Government Policy to inform, manage and control of Hepatitis B Virus infection.

- In Bangladesh we have a National T.V Channel, "BTV" and National Radio Channel "Bangladesh Betar" where there is no sufficient or effective campaign on the spread ability and severities of Hepatitis B virus infection. Though 95\% of Bangladeshi People watches on B.T.V or listen to Bangladesh Betar, this potential campaign mechanisms are ignored. By making informative, effective and interesting video or audio clips on spread ability, risk factor and severities of Hepatitis B virus infection can be sort of a successful \& effective campaign which helps to increase the knowledge, and practice related to Hepatitis $\mathrm{B}$ virus infection.

- In Bangladesh Hepatitis B Virus infection related knowledge should be added in the text of High School Level text book. Not before after this level. Because primary level age group student is too small to know and college level students is past away from this time to know.

- Another effective campaign can be done through bill boards and posters. As Bangladesh is a developing country people of both town and village are working in the industrial area, offices and many other organizations, while there way to anywhere, bill board and poster on the road can successfully draw the attention. So knowledge related to Hepatitis B virus easily risk to them.

- Campaign can be also done through health magazines, leaflets, newspaper and other media.

\section{Conclusion And Recommendations}

In developing countries like us, blood transfusion service have traditionally been a low priority in health service development, Recent concerns about disease transmission through blood transfusion have promoted frequent questions to physicians about the safety of transfusion. Hepatitis B virus is a preventable disease. A safe, effective blood transfusion service is the essential component to the provision off adequate health service. The persistent of HBV in the liver give rise to chronic active hepatitis, chronic persistent hepatitis. In this study it is observed that, the socio-demographic as well as risk of hepatitis B transmission and knowledge and practice play an important role in the occurrence of the hepatitis B virus infection in Bangladesh in a great extent.

This study found that male respondents are more likely to HBV infection. The male were 63 and female were 44, and among total $16 \mathrm{HBV}$ positive cases male were 12 and 4 were female, among them 1 married person is found HBV positive. In relation to the association of risk factors like sex practice 10 were exposed to girl/ boy friends. Among the male donors $63(59 \%)$ had history of shaving in saloons and $(41 \%)$ did not had history of shaving in saloons. Among a total of 16 positive cases 3 had status in relation to saloon shaves. The preponderance of $\mathrm{HBV}$ among young adults is a great concern for Bangladesh. For that knowledge and practice for health managing and safety risk of hepatitis $\mathrm{B}$ transmission should be increased.

On the basis of finding of the study the researcher puts forward following recommendation:

- HBV vaccination should be introduced among high-risk Individuals.

- In the Government and Non-Government level awareness should be increased about HBV transmission.

- All blood should be screened for HBV before transfusion.

- Minimizing unnecessary blood transfusion.

- Schemes to motivate and recruit donors from low risk community groups and where feasible, provide for pre-donation physical examination of donors with exclusion of those who have any risk features.

\section{References}

[1]. Alam, Mohbubul., M. Jahan, Shah., Md. Hague, Abidul., Md. Rahman, Shah Abdur., etal, 2000, " Hepatitis-B surface antigen among the professional and non-professional blood donors of Dhaka City", Journal of preventive and social medicine, Vol. 19, no.1, PP. 52-54.

[2]. Abdul-Mujib-S; Aamir-K; Mehmood-K, Seroprevalence of HBV, HCV and HIV infection among college going first time voluntary blood donors, JPMA-J-Pak-MedAssoc, Aug; 50 (8); 269-270.

[3]. Company, Davis. 2001, Taberis cyclopedic Medical Dictionary, Philadelphia, USA. CHOICETEXTS (ASIA) PTE. Ltd., Edt. 19, vol.2.

[4]. Company, Davis. 2001, Taberis cyclopedic $\quad$ Medical DictionaryPhiladelphia,USA.,CHOICETEXTS (ASIA) PTE. Ltd., Edt. 19, vol. 1.

[5]. Dr. Amanuallah, A.S.M., 2004, May, The Sociology of Mass Communication.

[6]. General Waiz, Anis., LT. Col. Md. Hossain, Rabiul, and Maj Fakir, Amzad Hossain, 1989, Hepatitis B profile in the armed forces-A clinical study of 93 cases, Bangladesh Armed Forces Medical Journal, Vol. XII, no.1, PP. 19-27.

[7]. Major Dr. Islam, Moinul, 2002, "Sero-prevalence of Hepatitis B-Surface antigen among non-professional blood donors in BSMMU", Armed forces medical institute Dhaka cantonment, MPH (Public Health) Course master in public health, Dhaka

[8]. Nurse GT. Blood transfusion and viruses with delayed expression (editorial) South African medical Journal. 1993 April; 83 (4): $235-6$. 
[9]. Neuman Lawrence, Social Research Methods, $3^{\text {rd }}$ edt., University of Wisconsin at whitewater.

[10]. Professor Khan, Mobin. 1998, "Hepatitis B vaccination-Present trend," Journal of medical teachers Federation, Vol.3, no.2, PP. 33-39.

[11]. Public health report, 2007, July Journal of the Royal Institutive of Public health, Vol. 121, no. 7,PP. 32-39.

[12]. 8)Public health report, 2007, January and February. Journal of the Royal Institute of Public Health, Vol. 122, no.1, PP. 2539.

[13]. Shahidullah, M., Hafez, M.A., M. Rahman, Mozibur., and Hossain, M.M. 1998, " Hepatitis B Surface antigen among non-professional blood donors in IPGM and R", Journal of preventive \& social medicine, Vol. 17, no.2, PP. 116-120

[14]. Sobeslauski, 0 prevalence of hepatitis B markers of hepatitis B infection in various countries: A WHO collaboration study. Bull. WHO 1980; 58 (4)

[15]. A vaccine against hepatitis B has been available since 1982. Hepatitis B vaccine is $95 \%$ effective in preventing infection and its chronic consequences, and was the first vaccine against a major human cancer.

\section{Websites}

[1]. http://www.who.int/mediacentre/factsheets/fs204/en/

[2]. http://en.wikipedia.org/wiki/Hepatitis_B

[3]. http://www.medicinenet.com/hepatitis_b/article.htm

[4]. http://en.wikipedia.org/wiki/Hepatitis_B_in_China

[5]. J Gastroenterol Hepatol. 2000 Dec;15(12):1356-61.(Chronic hepatitis B virus infection in Asian countries. Merican I, Guan R, Amarapuka D, Alexander MJ, Chutaputti A, Chien RN, Hasnian SS, Leung N, Lesmana L, Phiet PH, Sjalfoellah Noer HM, Sollano J, Sun HS, Xu DZ).http://www.ncbi.nlm.nih.gov/pubmed/11197043 